AperTO - Archivio Istituzionale Open Access dell'Università di Torino

\title{
ACUTE ADMINISTRATION OF ALPRAZOLAM, A BENZODIAZEPINE ACTIVATING GABA RECEPTORS, INHIBITS CORTISOL SECRETION IN PATIENTS WITH SUBCLINICAL BUT NOT OVERT CUSHING'S SYNDROME
}

\section{This is the author's manuscript}

Original Citation:

\section{Availability:}

This version is available http://hdl.handle.net/2318/118341

since 2016-07-16T10:55:43Z

Published version:

DOI:10.1007/s11102-012-0433-5

Terms of use:

Open Access

Anyone can freely access the full text of works made available as "Open Access". Works made available under a Creative Commons license can be used according to the terms and conditions of said license. Use of all other works requires consent of the right holder (author or publisher) if not exempted from copyright protection by the applicable law. 
This is the author's final version of the contribution published as:

R. Giordano; R. Berardelli; I. Karamouzis; V. D’Angelo; A. Picu; C. Zichi.;

B. Fussotto; M. Manzo; G. Mengozzi; E. Ghigo; E. Arvat. ACUTE

ADMINISTRATION OF ALPRAZOLAM, A BENZODIAZEPINE

ACTIVATING GABA RECEPTORS, INHIBITS CORTISOL SECRETION

IN PATIENTS WITH SUBCLINICAL BUT NOT OVERT CUSHING'S

SYNDROME. PITUITARY. 16 (3) pp: 363-369.

DOI: $10.1007 / \mathrm{s} 11102-012-0433-5$

The publisher's version is available at:

http://link.springer.com/content/pdf/10.1007/s11102-012-0433-5

When citing, please refer to the published version.

Link to this full text:

http://hdl.handle.net/2318/118341 
ACUTE ADMINISTRATION OF ALPRAZOLAM, A BENZODIAZEPINE ACTIVATING GABA RECEPTORS, INHIBITS CORTISOL SECRETION IN PATIENTS WITH SUBCLINICAL BUT NOT OVERT CUSHING'S SYNDROME

ROBERTA GIORDANO • RITA BERARDELLI • IOANNIS KARAMOUZIS • VALENTINA D'ANGELO •

ANDREEA PICU • CLIZIA ZICHI • BEATRICE FUSSOTTO • MARIA MANZO・ GIULIO MENGOZZI • EZIO GHIGO • EMANUELA ARVAT

R. GIORDANO (\&)

DEPARTMENT OF CLINICAL AND BIOLOGICAL SCIENCES, UNIVERSITY OF TURIN, ORBASSANO, ITALY E-MAIL: ROBERTA.GIORDANO@UNITO.IT R. BERARDELLI • I. KARAMOUZIS • V. D’ANGELO •

A. PICU • C. ZICHI • B. FUSSOTTO • E. GHIGO • E. ARVAT DIVISION OF ENDOCRINOLOGY, DIABETOLOGY AND METABOLISM, DEPARTMENT OF INTERNAL MEDICINE, UNIVERSITY OF TURIN, SAN GIOVANNI BATTISTA HOSPITAL, TURIN, ITALY M. MANZO • G. MENGOZZI CLINICAL BIOCHEMISTRY LABORATORY, SAN GIOVANNI BATTISTA HOSPITAL, TURIN, ITALY

Key-words: Alprazolam • Cortisol • Dexamethasone test $・$ Subclinical Cushing's syndrome 
ABSTRACT. The purpose of this study is to verify whether acute pre-treatment with alprazolam (ALP), a benzodiazepine that inhibits HPA secretion in normal subjects, could better characterize patients with subclinical Cushing's syndrome (SCS) than the 1-mg dexamethasone test (DST).

In 22 patients with SCS, 10 with overt Cushing's syndrome (CS), 11 with non-functioning adrenal incidentalomas (NF) and 14 normal subjects (NS) we studied the effect of ALP (1 mg, p.o. at 2300 hours) on cortisol levels after 1-mg DST. Cortisol levels (mean \pm SEM) after DST were lower $(\mathrm{P}=0.012)$ in SCS $(3.9 \pm 0.3 \mu \mathrm{g} / \mathrm{dl})$ than in overt CS $(10.4 \pm 1.9 \mathrm{lg} / \mathrm{dl})$, while they were higher $(\mathrm{P}=0.0005)$ than in NF $(1.1 \pm$ $0.1 \mu \mathrm{g} / \mathrm{dl})$ and NS $(1.5 \pm 0.1 \mu \mathrm{g} / \mathrm{dl})$. After ALP pre-treatment, cortisol levels further decreased $(\mathrm{P}=0.004)$ in SCS $(3.0 \pm 0.3 \mathrm{lg} / \mathrm{dl})$, but neither in CS $(9.3 \pm 1.3 \mathrm{lg} / \mathrm{dl})$ nor in NF $(1.3 \pm 0.1 \mu \mathrm{g} / \mathrm{dl})$ and in NS $(1.3 \pm 0.1$ $\mu \mathrm{g} / \mathrm{dl})$. In SCS, cortisol levels after ALP +1 -mg DST persisted lower $(\mathrm{P}=0.0005)$ than those in CS, but higher $(\mathrm{P}=0.0005)$ than those in NF and NS. Considering individual cases, ALP pre-treatment reduced cortisol levels $<3$ and a1.8 $\mathrm{lg} / \mathrm{dl}$ in 50 and $23 \%$ of SCS patients, respectively. ALP amplifies the cortisol inhibition exerted by 1-mg DST in patients with SCS but not in those with CS. The clinical usefulness of ALP to increase the sensitivity of 1-mg DST to identify true autonomous cortisol release in patients with adrenal incidentalomas as well as to predict different clinical outcomes remains to be clarified. 


\section{Introduction}

Subclinical Cushing's syndrome (SCS) is defined as a status of altered hypothalamic-pituitary-adrenal (HPA) axis secretion characterized by an autonomous and unreg- ulated cortisol secretion, not fully restrained by pituitary feedback, in the absence of the classical signs or symptoms of overt cortisol excess [1-5].

Subclinical Cushing's syndrome was initially reported around 30 years ago in patients studied for incidentally discovered adrenal masses $[6,7]$, the so called adrenal incidentalomas, that have become a common finding in clinical practice. In fact, the widespread use of abdominal ultrasonography, computed tomography (CT) and magnetic resonance imaging (MRI), have led to an increase in the detection of adrenal incidentalomas in recent years, rang- ing between 1 and $8.7 \%$ [8]; the interest of SCS in this population is due to its high prevalence, ranging between 5 and $30 \%$ of different series $[4,5]$.

Among the various tests used for the diagnosis of SCS, the 1-mg dexamethasone test (DST) is considered the most valuable test to screen for SCS, either alone or in combi- nation with other parameters $[4,5]$. Dexamethasone is a synthetic glucocorticoid (GC) with selectivity for gluco- corticoid receptor (GR), that preferentially activates pitui- taric GRs and has been extensively employed to assess the integrity of the HPA-axis feed-back $[9,10]$. It is used to evaluate the status of the HPA axis in adrenal inciden- talomas, applying concepts derived by screening of overt cortisol excess [11]. The 1-mg DST cortisol cut-off is still a matter of debate, being the cut-off of $1.8 \mathrm{lg} / \mathrm{dl}(50 \mathrm{nmol} / \mathrm{l})$ considered as having the highest sensitivity [4, $5,8,12-14]$, while the cut-off of $3.0 \mathrm{lg} / \mathrm{dl}(83 \mathrm{nmol} / \mathrm{l})$ has been demonstrated by some Authors as having the best com- promise between sensitivity and specificity [4]. On the other hand, the Endocrine Society Clinical Guidelines for the diagnosis of Cushing's syndrome recommended the cut-off for of $1.8 \mathrm{lg} / \mathrm{dl}$ for the initial hormonal evaluation of patients with suspected overt cortisol excess [11].

Alprazolam (ALP), a benzodiazepine (BDZ) activating c-amino butyric acid (GABA)-ergic receptors, exhibits a clear inhibitory effect on HPA axis secretion $[15,16]$ through an inhibitory influence on CRHand/or AVP secreting neurons $[15,16]$. In fact, in normal subjects ALP inhibits the ACTH and cortisol responses to several stimulations, such as vasopressin, metabolic and mental stress, naloxone and synthetic GH-secretagogues [17-22]. Moreover, although ALP failed to modify CRH-induced ACTH secretion from rat pituitary [15] and it does not inhibit the ACTH and cor- tisol responses to exogenous CRH in humans $[19,23]$, the existence of GABA/BDZ receptors in the pituitary gland suggested a direct modulatory role of 
GABA and/or BDZ on corticotroph secretion induced by ACTH secretagogues other than CRH $[15,16]$. Moreover, ALP did show a marked inhibitory effect even on ACTH rise induced by metyrapone or insulininduced hypoglycemia, the most potent stimula- tions of corticotroph secretion [24, 25], as well as on HPA response to the blockade of mineralocorticoid receptors [26], clearly indicating a primary role of GABAergic pathways in the modulation of HPA activity in physiological conditions. There is evidence that ALP still inhibits, though with less potency, HPA response to different ACTH secreta- gogues in clinical conditions characterized by functional HPA hyperactivity, such as obesity [22], while it does not modify ACTH and cortisol responses in patients with overt Cushing's syndrome [22, 27], suggesting that the inhibitory influence of GABA/BDZ is lost in patients with organic hypercortisolism.

Interestingly, ALP has been demonstrated to also bind to the peripheral benzodiazepine receptors (PBR), structurally and functionally different to GABA receptors, that have been shown to play a critical role in steroidogenetic pro- cesses leading to the synthesis of both neurosteroids and steroid hormones in adrenal gland; moreover, they also exert a modulator influence on the activity of the anterior pituitary gland [28, 29].

Based on these premises, the aim of the present study was to verify the effect of acute ALP pre-treatment on cortisol response to 1-mg DST in patients with SCS, comparing them with patient with overt CS, nonfunctioning adrenal adenomas and normal subjects.

\section{Subjects and methods}

Thirty-three consecutive patients $(21 \mathrm{~F}$ and $12 \mathrm{M}$; age $57.4 \pm 1.2$ years $)$ with adrenal masses incidentally dis- covered by abdominal CT or MRI, 10 patients with overt Cushing's syndrome (CS, $9 \mathrm{~F}$ and $1 \mathrm{M}$; age $53.0 \pm 3.2$ years $)$ due to either cortisol-secreting adenomas $(\mathrm{n}=5)$ or ACTH-secreting pituitary adenomas $(\mathrm{n}=5$ ), and 14 normal subjects (NS, $7 \mathrm{~F}$ and $7 \mathrm{M}$; age $54.6 \pm 3.4$ years) were studied. Patients with adrenal incidentalomas were further subdivided into two groups: 1 ) with SCS ( $\mathrm{n}=22 ; 14 \mathrm{~F}$ and $8 \mathrm{M}$; age $58.1 \pm 1.2$ years); 2) with non-functioning adrenal adenomas (NF; $\mathrm{n}=11 ; 7 \mathrm{~F}$ and $4 \mathrm{M}$; age $55.9 \pm$ 2.9 years). The diagnosis of SCS was based on a post 1 -mg-DST cortisol level $[1.8 \mu \mathrm{g} / \mathrm{dl}(50 \mathrm{nmol} / \mathrm{l})$ combined with an abnormal result in at least one of the following tests: (1) post-low dose dexamethasone suppression test (LDDST) cortisol levels $[1.8 \mu \mathrm{g} / \mathrm{dl}(50 \mathrm{nmol} / \mathrm{l}) ;(2)$ absence of cortisol rhythm [midnight 
serum cortisol [7.5 $\mu \mathrm{g} / \mathrm{dl}(220 \mathrm{nmol} /)]$; (3) low ACTH levels [<5 pg/ml (1.1 pmol/l)]; (4) high UFC [[100 $\mu \mathrm{g} / 24 \mathrm{~h}(275 \mathrm{mmol} / 24 \mathrm{~h})]$, in the absence of clinical signs or symptoms of cortisol excess.

The diagnosis of CS as well as the differentiation between ACTH-dependent and ACTH-independent was based on International Guidelines [11]. The patient with ACTH- dependent CS underwent pituitary MRI that detected a micro-adenoma in all cases.

All the subjects gave their informed consent to partici- pate in the study, which had been approved by the local ethical committee, in agreement with the Declaration of Helsinki.

All the subjects underwent 1-mg DST (1 mg dexameth asone administered orally at 2300 hours, and blood sample drawing on the following morning at 0800 hours for deter mination of serum cortisol concentration) and alprazolam (ALP, $1 \mathrm{mg}$ administered orally at 2200 hours) + 1-mg DST.

Serum cortisol levels $(1 \mu \mathrm{g} / \mathrm{dl} 927.7=1 \mathrm{nmol} / \mathrm{l}$; nor- mality, range 6.2-19.4 $\mu \mathrm{g} / \mathrm{dl})$ were measured in duplicate by competitive electrochemiluminescence immunoassay on cobas e601 instrument (Roche Diagnostics GmbH, Sandhofer Strasse 116, D-68305 Mannheim, Germany), with the sensitivity of the assay that was $0.01 \mu \mathrm{g} / \mathrm{dl}$ and the intra- and inter-assay coefficients of variations that ranged from 3.0 to 5.7 $\%$ and from 2.4 to $6.2 \%$, respectively.

Plasma ACTH levels $(1 \mathrm{pg} / \mathrm{ml} 90.22=1 \mathrm{pmol} / \mathrm{l}$; nor- mality, range 5-46 pg/ml) were measured in duplicate by Immulite 2000 (Siemens Healthcare Diagnostics Inc., Llanberis, Gwynedd LL55 4EL, UnitedKingdom), with the sensitivity of the assay that was $5 \mathrm{pg} / \mathrm{ml}$, and the inter-and intra-assay coefficients of variation that ranged from 6.1 to $10 \%$ and from 6.7 to $9.5 \%$, respectively.

Urinary free cortisol levels (UFC, $1 \mu \mathrm{g} / 24$ h $92.75=1 \mathrm{nmol} / \mathrm{d}$; normality, range 10-90 lg/24 h) were measured in duplicate by micro particle-based chemiluminescence auto- mated on Architect i2000 analyzer without extraction (Abbott Diagnostics, Abbott Park, IL, USA), with the sensitivity of the assay that was $1.0 \mu \mathrm{g} / 24 \mathrm{~h}$ and the inter-and intra-assay coefficients of variation that ranged from 4.2 to $8.9 \%$ and from 4.7 to $11.5 \%$, respectively.

\section{Statistical analysis}

The data were expressed as mean \pm SEM. 
All statistical analyses were performed using Statistical Package for the Social Science (SPSS 19.0 for Windows: SPSS Inc., 1989-2005, Chicago IL, USA) [30]. A value of $\mathrm{P}<0.05$ was considered to be significant.

The statistical analysis was carried out by using non- parametric Mann-Whitney test for the comparison between groups and the Wilcoxon test for the comparison between two testing sessions in the same group of patients.

Correlations between cortisol levels after ALP + 1-mg DST and midnight serum cortisol, ACTH levels and UFC in SCS patients were carried out by using the Pearson correlation coefficient and multiple linear regression anal- ysis among the above variables was then performed.

Results

Cortisol levels (mean $\pm \mathrm{SEM})$ after 1 -mg DST were lower $(\mathrm{P}=0.012)$ in SCS $(3.9 \pm 0.3 \mu \mathrm{lg} / \mathrm{dl})$ than in overt CS $(10.4 \pm 1.9 \mu \mathrm{g} / \mathrm{dl})$, while they were higher $(\mathrm{P}=0.0005)$ than those in NF $(1.1 \pm 0.1 \mathrm{lg} / \mathrm{dl})$ and NS $(1.5 \pm 0.1 \mu \mathrm{g} / \mathrm{dl})$. Considering individual cases, 1-mg DST inhibited cortisol levels $<3 \mu \mathrm{g} / \mathrm{dl}$ in 8 SCS patients $(36 \%$, cases 1, 3, 5, 12, 13, 14, 15, 20) (Table 1; Figs. 1, 2).

After ALP pre-treatment cortisol levels further decreased $(\mathrm{P}=0.04)$ in SCS $(3.0 \pm 0.3 \mu \mathrm{g} / \mathrm{dl})$, but neither in CS $(9.3 \pm 1.3 \mu \mathrm{g} / \mathrm{dl})$ nor in NF $(1.3 \pm 0.1 \mu \mathrm{g} / \mathrm{dl})$ and in NS $(1.3 \pm 0.1 \mu \mathrm{g} / \mathrm{dl})$. In SCS, cortisol levels after ALP ? 1-mg DST persisted lower $(\mathrm{P}=0.0005)$ than those in CS, but higher $(\mathrm{P}=0.0005)$ than those in NF and NS (Table 1; Fig. 1).

Considering individual cases, cortisol levels after ALP + 1-mg DST were [ $3 \mu \mathrm{g} / \mathrm{dl}$ in all CS patients, while ALP did not further inhibit post DST cortisol levels in none of NF and NS subjects. On the contrary, ALP pre-treatment further reduced cortisol levels $<3 \mathrm{lg} / \mathrm{dl}$ in 11 SCS patients $(50 \%$, cases $4,5,7,8,9,10,12$, $15,17,18,20)$ and $<1.8 \mathrm{lg} / \mathrm{dl}$ in 5 SCS patients ( $23 \%$, cases $4,7,8,15,18)$ (Table 1; Fig. 2).

In SCS a significant positive correlation between corti- sol levels after ALP + 1-mg DST and midnight serum cortisol levels was found $(r=0.44, \mathrm{P}=0.04)$, while no significant correlation between cortisol levels after ALP + 1-mg DST and ACTH levels or UFC was found.

At the multiple regression analysis, in SCS midnight serum cortisol was the best predictor of cortisol levels after ALP + 1-mg DST $(b=0.48, P=0.02)$. 


\section{Discussion}

The results of this study show that ALP, a benzodiazepine activating GABA-ergic receptors, amplified the cortisol inhibition exerted by 1-mg DST in patients with subclinical Cushing's syndrome, while it did not modify the cortisol levels in those with overt Cushing's syndrome.

The inhibitory effect of GABA/BDZ receptor activation on HPA activity has previously been demonstrated in both animals and humans. Among the various BDZ commonly used in clinical practice, ALP showed so far the most remarkable inhibitory effect on the HPA axis, being evi- dent on both basal and stimulatedACTH and cortisol secretion, at least in physiological conditions $[15,16]$. In fact, ALP has been shown to significantly reduce basal corticotroph and adrenal secretion either in animals [15] or in humans [16, 24, 31]. On the other hand, ALP has been shown to significantly blunt the HPA response to several stimulations; in particular, while in animals it has been demonstrated to inhibit the corticotroph response to insulin- induced hypoglicemia and serotonin-stimulated CRH secre tion [15], in humans it significantly decreases the ACTH/ cortisol response to metyrapone and insulin-induced hypo-glycemia, the most potent stimulations of corticotroph secretion [24, 25].

About mechanisms of action, either CRH- or AVP- mediated central actions has been hypothesized. In particular, ALP has been demonstrated to act at hypothalamic level, via inhibition of CRH release, being able to inhibit the ACTH and cortisol response to CRH-mediated stimuli, to AVP but not to exogenous CRH [17-20, 24]. On the other hand, other studies indicate that ALP could act via AVP-mediated mechanisms [27], although some authors did not find any significant effect of ALP on AVP release in humans [23]. It has also been proposed that ALP may influence HPA axis by acting at supra-hypothalamic level, as it has been shown to counteract the stimulatory effects of substances which reduce the GCmediated negative feed-back by acting at supra-hypothalamic level [24, 26]. Moreover, although BDZ failed to modify $\mathrm{CRH}$-induced $\mathrm{ACTH}$ secretion from rat pituitary [15], the existence of GABA/BDZ receptors in the pituitary gland suggested a direct modulator role of GABA and/or BDZ on cortico- troph secretion induced by ACTH secretagogues other than CRH.

Our present results showing that ALP partially amplifies the cortisol inhibition exerted by $1 \mathrm{mg}$ DST in patients with subclinical hypercortisolism suggest that GABA/BDZ system still modulates cortisol secretion in these patients, indicating that this condition is not characterized by a complete ACTH independence of cortisol secretion. Con versely, in patients with overt Cushing's syndrome, both pituitary ACTH-secreting 
and cortisol-secreting adrenal adenomas, ALP did not modify cortisol response to $1 \mathrm{mg}$ DST, confirming previous data in literature demonstrating that these patients are not sensitive to the inhibitory effects of GABA/BZD [22, 27].

In this context, we hypothesized that ALP could be more effective in subclinical Cushing's syndrome patients with non- suppressed ACTH levels, suggesting in these patients a more clear ACTH dependence of cortisol secretion, possibly reflecting a somewhat functional HPA hyperactivation and not a true autonomous cortisol secretion. Unfortunately, we did not find a significant correlation between basal ACTH levels and suppression of cortisol after ALP + DST. This may simply reflect the small number of subjects enrolled in our study, although the hypothesis that in these patients the cortisol inhibiting effect of GABA/BZD does occur independently of ACTH levels cannot be excluded.

Our present results showing a positive correlation between cortisol levels after ALP + 1-mg DST and midnight serum cortisol levels in SCS are in agreement with previous reports showing an individual set point of sensitivity to the mechanisms controlling HPA activity [32], again suggesting a somewhat functional HPA hyperactivation and not a true autonomous cortisol secretion in these patients; moreover, similarly to what reported in patients with overt Cushing's syndrome [11], both these hormonal alterations may be the earliest and most sensitive markers of endoge- nous glucocorticoid excess in these patients.

Finally, a peripheral effect of ALP on adrenal gland can be hypothesized. In fact, ALP has been demonstrated to act, in the adrenal gland, through PBR, structurally and functionally different to GABA receptors, that play a critical role in steroidogenetic processes involved in the synthesis of both neurosteroids and peripheral steroid hormones [28, 29]. Although PBR activation by BDZ has been demonstrated to stimulate steroidogenesis in the adrenal gland by some authors, other studies showed an inhibitory effect of BDZ on ACTH-induced steroidogenesis in ani- mals [28, 29, 33]. The inhibitory effect on adrenal secretion induced by the activation of PBR system could explain the ALP effect on cortisol response to DST in our subclinical hypercortisolemic patients, in agreement with previous data showing that ALP significantly blunts the adrenal response to low ACTH doses in humans [23]. Conversely, the absence of modulation by ALP on cortisol secretion in patients with overt Cushing's syndrome would suggest that PBR system is unable to overcome the strong stimulatory effect induced by either autonomous adrenal adenoma or exaggerated ACTH stimulation on cortisol release. 
Although the clinical usefulness of ALP to increase the sensitivity of 1-mg DST in patients with adrenal inciden- talomas remains to be clarified, it's noteworthy that with the cortisol cut-off of $1.8 \mu \mathrm{g} / \mathrm{dl}$ (50 nmol/1), about $23 \%$ of patients classified as affected by SCS using 1-mg DST would be considered normal after ALP pre-treatment. Moreover, by using the cutoff of $3.0 \mathrm{lg} / \mathrm{dl}(83 \mathrm{nmol} / \mathrm{l})$, that represents the best compromise between sensitivity and specificity accordingly to the opinion of some expert [4], $50 \%$ of patients classified as affected by SCS by using 1-mg DST would be considered normal after ALP pretreatment.

Our choice of screening for SCS with a lower cut-off than those recommended for adrenal incidentalomas by international guidelines $[8,12,14]$ could have led us to a decrease in specificity and, therefore, to more false diag- nosis of SCS, but it was needed for the comparison with CS patients, accordingly to The Endocrine Society Clinical Guidelines [11]. On the other hand, this was the cut-off recommended by the French Society of Endocrinology in patients with adrenal incidentalomas [13].

Recognizing the limitation of any single test of the HPA axis activity, ALP ? 1-mg DST might become a new tool for the diagnosis of SCS in patients with adrenal inciden- talomas with not concordant results provided that patients with suppression of cortisol levels after ALP ? $1 \mathrm{mg}$ DST below $\backslash 1.8 \mathrm{lg} / \mathrm{dl}$ show a different progression of the dis- ease, in term of hormonal, clinical and morphological parameters during a long-term follow up compared with the non-suppressing patients. On the other hand, the doubt remains as to whether the patients defined as SCS are really hypercortisolemic and whether the ALP ? 1-mg DST is really capable of distinguishing SCS from NF amongst

patients with adrenal incidentaloma.

In conclusion, this study shows that ALP amplifies the cortisol inhibition exerted by 1-mg DST in patients with subclinical hypercortisolism but not in those with overt hypercortisolism. A not complete ACTH independence of cortisol secretion and/or a peripheral adrenal inhibiting GABA/BZD effect is suggested in subclinical Cushing's syndrome patients. The clinical usefulness of ALP to increase the sensitivity of 1-mg 
DST for the diagnosis of subclinical Cushing's syndrome in patients with adrenal incidentalomas as well as to predict different clinical out- comes remains to be clarified.

Acknowledgments The present study was supported by University of Turin and the Foundation for the Study of Endocrine and Metabolic Diseases.

Conflict of interest The authors declare that they have no conflict of interest.

\section{References}

1. Reincke M (2000) Subclinical Cushing's syndrome. Endocrinol Metab Clin North Am 29:43-56

2. Terzolo M, Reimondo G, Bovio S, Angeli A (2004) Subclinical Cushing's syndrome. Pituitary $7: 217-223$

3. Tsagarakis S, Vassiliadi D, Thalassinos N (2006) Endogenous subclinical hypercortisolism: diagnostic uncertainties and clinical implications. J Endocrinol Invest 29:471-482

4. Chiodini I (2011) Diagnosis and treatment of subclinical hyper- cortisolism. J Clin Endocrinol Metab 96:1223-1236

5. Terzolo M, Pia A, Reimondo G (2012) Subclinical Cushing's syndrome: definition and management. Clin Endocrinol 76:12-18

6. Beierwaltes WH, Sturman MF, Ryo U, Ice RD (1973) Imaging functional nodules of adrenal gland with 131-I-9iodocholesterol. J Nucl Med 15:246-251

7. Charbonnel B, Chatal JF, Ozanne P (1981) Does the corticoad- renal adenoma with "pre-Cushing's syndrome'” exist? J Nucl Med 22:1059-1061

8. Terzolo M, Stigliano A, Chiodini I, Loli P, Furlani L, Arnaldi G, Reimondo G, Pia A, Toscano V, Zini M, Borretta G, Papini E, Garofalo P, Allolio B, Dupas B, Mantero F, Tabarin A (2011) Italian 
association of clinical endocrinologists. AME position statement on adrenal incidentaloma. Eur J Endocrinol 164: 851-870

9. Cole MA, Kim PJ, Kalman BA, Spencer RL (2000) Dexameth- asone suppression of corticosteroid secretion: evaluation of the site of action by receptor measures and functional studies. Psy- choneuroendocr $25: 151-167$

10. Feldman S, Weidenfeld J (2002) Further evidence for the central effect of dexamethasone at the hypothalamic level in the negative feedback mechanism. Brain Res 958:291-296

11. Nieman LK, Biller BM, Findling JW, Newell-Price J, Savage MO, Stewart PM, Montori VM (2008) The diagnosis of Cush- ing's syndrome: an endocrine society clinical practice guideline. J Clin Endocrinol Metab 93:1526-1540

12. Grumbach MM, Biller BM, Braunstein GD, Campbell KK, Carney JA, Godley PA, Harris EL, Lee JK, Oertel YC, Posner MC, Schlechte JA, Wieand HS (2003) Management of the clin- ically inapparent adrenal mass ('incidentaloma'). Ann Int Med 138:424-429

13. Tabarin A, Bardet S, Bertherat J, Dupas B, Chabre O, Hamoir E, Laurent F, Tenenbaum F, Cazalda M, Lefebvre H, Valli N, Rohmer V (2008) Exploration and management of adrenal inci- dentalomas. French Society of Endocrinology Consensus. Ann Endocrinol (Paris) 69:487-500

14. Zeiger MA, Thompson GB, Duh QY, Hamrahian AH, Angelos P, Elaraj D, Fishman E, Kharlip J (2009) American association of clinical endocrinologists; American association of endocrine surgeons: The American Association of Clinical Endocrinologists and American Association of Endocrine Surgeons medical guidelines for the management of adrenal incidentalomas. Endocr Pract 15(Suppl. 1):1-20

15. Kalogeras KT, Calogero AE, Kuribayashi T, Khan I, Gallucci WT, Kling MA, Chrousos GP, Gold PW (1990) In vitro and in vivo effects of the triazolobenzodiazepine alprazolam on hypo- thalamicpituitary-adrenal function: pharmacological and clinical implications. J Clin Endocrinol Metab 70:14621471

16. Arvat E, Giordano R, Grottoli S, Ghigo E (2002) Benzodiazepine and anterior pituitary function. J Endocrinol Invest 25:735-747 
17. Breier A, Davis O, Buchanan R, Listwak SJ, Holmes C, Pickar D, Goldstein DS (1992) Effects of alprazolam on pituitary-adrenal and catecholaminergic responses to metabolic stress in humans. Biol Psychiatry 32:880-890

18. Torpy DJ, Grice JE, Hockings GI, Walters MW, Crosbie GV, Jackson RV (1993) Alprazolam blocks the naloxone-stimulated hyphotalamic-pituitary-adrenal axis in man. J Clin Endocrinol Metab 76:388-391

19. Roher T, von Richthofen V, Schulz C, Beyer J, Lehnert H (1994) The stress, but not corticotropinreleasing hormone-induced activation of the pituitary-adrenal axis in man is blocked by alprazolam. Horm Metab Res 26:200-206

20. Torpy DJ, Grice JE, Hockings GI, Walters MW, Crosbie GV, Jackson RV (1994) Alprazolam attenuates vasopressin-stimulated adrenocorticotropin and cortisol release: evidence for sinergy between vasopressin and corticotropin-releasing hormone in humans. J Clin Endocrinol Metab 79:140-144

21. Arvat E, Maccagno B, Ramunni J, Di Vito L, Gianotti L, Broglio F, Benso A, Deghenghi R, Camanni F, Ghigo E (1998) Effects of dexametasone and alprazolam, a benzodiazepine, on the stimulatory effect of Hexarelin, a synthetic GHRP, on ACTH, cortisol and GH secretion in humans. Neuroendocrinology 67:310-316

22. Grottoli S, Arvat E, Gauna C, Maccagno B, Ramunni J, Giordano R, Maccario M, Deghenghi R, Ghigo E (1999) Effects of alprazolam, a benzodiazepine, on the ACTH, GH- and PRL- releasing activity of Hexarelin, a synthetic peptidyl GH secreta- gogue (GHS), in patients with simple obesity and in patients with Cushing's disease. Pituitary 2:197-204

23. Grottoli S, Maccagno B, Ramunni J, Di Vito L, Giordano R, Gianotti L, Destefanis S, Camanni F, Arvat E (2002) Alprazolam, a benzodiazepine, does not modify the ACTH and cortisol response to CRH and AVP, but blunts the cortisol response to ACTH in humans. J Endocrinol Invest 25:420-425

24. Arvat E, Maccagno B, Ramunni J, Di Vito L, Giordano R, Gianotti L, Broglio F, Camanni F, Ghigo E (1999) The inhibitory effect of alprazolam, a benzodiazepine, overrides the stimulated effect of metyrapone-induced lack of negative cortisol feedback on corticotroph secretion in humans. J Clin Endocrinol Metab 84:2611-2615 
25. Giordano R, Grottoli S, Brossa PC, Pellegrino M, Destefanis S, Lanfranco F, Gianotti L, Ghigo E, Arvat E (2003) Alprazolam (a benzodiazepine activating GABA receptor) reduces the neuro- endocrine responses to insulin induced hypoglycaemia in humans. Clin Endocrinol 53:314-320

26. Grottoli S, Giordano R, Maccagno B, Pellegrino M, Ghigo E, Arvat E (2002) The stimulatory effect of canrenoate, a mineral- ocorticoid antagonist, on the activity of the hypothalamus-pitui- tary-adrenal axis is abolished by alprazolam, a benzodiazepine, in humans. J Clin Endocrinol Metab 87:4616-4620

27. Korbonits M, Trainer PJ, Edwards R, Besser GM, Grossman AB (1995) Benzodiazepines attenuate the pituitary-adrenal responses to corticotrophin-releasing hormone in healthy volunteers, but not in patients with Cushing's syndrome. Clin Endocrinol 43:29-35

28. Papadopoulos V (1993) Peripheral-type benzodiazepine/diaze- pam binding inhibitor receptor: biological role in steroidogenic cell function. Endocr Rev 14:222-240

29. Whitehouse BJ (1992) Benzodiazepines and steroidogenesis. J Endocrinol 134:1-3

30. Nelder JA (1974) A user's guide to the evaluation of statistical packages and systems. Int Stat Rev 42:291-298

31. Lopez AL, Kathol RG, Noyes R Jr (1990) Reduction in urinary free cortisol during benzodiazepine treatment of panic disorder. Psychoneuroendocrinology 15:23-28

32. Huizenga NA, Koper JW, de Lange P, Pols HA, Stolk RP, Grobbee DE, de Jong FH, Lamberts SW (1998) Interperson variability but intraperson stability of baseline plasma cortisol concentrations, and its relation to feedback sensitivity of the hypothalamo-pituitary-adrenal axis to a low dose of dexametha- sone in elderly individuals. J Clin Endocrinol Metab 83:47-54

33. Calogero AE, Kamilaris TC, Bernardini R, Johnson EO, Chrou- sos GP, Gold PW (1990) Effects of peripheral benzodiazepine receptor ligands on hypothalamic-pituitary-adrenal axis function in the rat. J Pharmacol Exp Ther 253:729-737 
The authors wish to thank Denis Gailor for the final editing of the manuscript.

Declaration of interest

The authors declare that there is no conflict of interest that could be per- ceived as prejudicing the impartiality of the research reported.

Funding

This study was supported in part by a grant from the European Union Sixth Framework Programme, the EurAPS project: Autoimmune Polyen- docrine Syndrome type I-a rare disorder of childhood as a model for au- toimmunity, contract number 2005-005223, and in part by a grant from the European Union Seventh Framework Programme, the Euradrenal pro- ject: Pathophysiology and Natural Course of Autoimmune Adrenal Fail- ure in Europe. Grant Agreement No. 2008-201167.

\section{REFERENCES}

1. Kahaly GJ. Polyglandular autoimmune syndromes. Eur J Endocrinol 2009, 161: 11-20.

2. Ahonen P, Myllärniemi S, Sipilä I, Perheentupa J. Clinical variation of autoimmune polyendocrinopathy-candidiasis-ectodermal dys- trophy (APECED) in a series of 68 patients. New Engl J Med 1990, 322: 1829-36.

3. Husebye ES, Perheentupa J, Rautemaa R, Kämpe O. Clinical man- ifestation and management of patients with autoimmune polyen- docrine syndrome type 1. J Intern Med 2009, 265: 514-29.

4. Peterson P, Peltonen L. Autoimmune polyendocrinopathy syn- drome type-1 (APS 1) and AIRE gene: New views on molecular ba- sis of autoimmunity. J Autoimmun 2005, 25: 49-55.

5. Aaltonen J, Bjorses P, Sandkuijl L, Perheentupa J, Peltonen L. An autosomal locus causing autoimmune disease: autoimmune polyg- landular disease type I assigned to chromosome 21. Nat Genet 1994, 8: 83-7.

6. Zlotogora J, Shapiro MS. Polyglandular autoimmune syndrome type I among Iranian Jews. J Med Genet 1992, 29: 824-6.

7. The Finnish-German APECED Consortium. An autoimmune dis- ease, APECED, caused by mutations in a novel gene featuring two PHD-type zinc-finger domains. Autoimmune PolyendocrinopathyCandidiasis-Ectodermal Dystrophy. Nat Genet 1997, 17: 399-403. 
8. Nagamine K, Peterson P, Scott HS, et al. Positional cloning of the APECED gene. Nat Genet 1997, 17: $393-8$.

9. Heino M, Peterson P, Kudoh J, et al. APECED mutations in the au- toimmune regulator (AIRE) gene. Hum Mutat 2003, 18: 205-11.

10. Cetani F, Barbesino G, Borsari S, et al. A novel mutation of the au- toimmune regulator gene in an Italian kindred with autoimmune polyendocrinopathy-candidiasis-ectodermal dystrophy, acting in a dominant fashion and strongly cosegregating with hypothyroid au- toimmune thyroiditis. J Clin Endocrinol Metab 2001, 86: 4747-52.

11. Mathis D, Benoist C. Aire. Annu Rev Immunol 2009, 27: 287-312.

12. Obermayer-Straub P, Strassburg CP, Manns MP. Autoimmune polyglandular syndrome type 1 . Clinic Rev Aller Immunol 2000, 18: 167-83.

13. Vogel A, Strassburg CP, Obermayer-Straub P, Brabant G, Manns MP. The genetic background of autoimmune polyendocrinopathy- candidiasis-ectodermal dystrophy and its autoimmune disease components. J Mol Med 2002, 80: 201-11.

14. Meloni A, Fiorillo E, Corda D, Perniola R, Cao A, Rosatelli MC. Two novel mutations of the AIRE protein affecting its homodimeriza- tion properties. Hum Mutat 2005, 25: 319.

15. Perheentupa J. Autoimmune polyendocrinopathy-candidiasis-ec- todermal dystrophy. J Clin Endocrinol Metab 2006, 91: 2843-50.

16. Cervato S, Mariniello B, Lazzarotto F, et al. Evaluation of the au- toimmune regulator (AIRE) gene mutations in a cohort of Italian patients with autoimmune-polyendocrinopathy-candidiasis-ecto- dermaldystrophy (APECED) and in their relatives. Clin Endocrinol 2009, 70: 421-8.

17. Rosatelli MC, Meloni A, Devoto M, et al. A common mutation in Sardinian autoimmune polyendocrinopathy-candidiasis-ectoder- mal dystrophy patients. Hum Genet 1998, 103: 428-34.

18. Meloni A, Perniola R, Faà V, Corvaglia E, Cao A, Rosatelli MC. Delineation of the molecular defects in the AIRE gene in autoim- mune polyendocrinopathycandidiasis-ectodermal dystrophy patients from Southern Italy. J Clin Endocrinol Metab 2002, 87: 841-6.

19. Betterle C, Dal Pra C, Mantero F, Zanchetta R. Autoimmune adrenal insufficiency and autoimmune polyendocrine syndromes: autoan- tibodies, autoantigenes, and their applicability in diagnosis and disease prediction. Endocr Rev 2002, 23: 327-64. 
20. Capalbo D, Mazza C, Giordano R, et al. Molecular background and genotype-phenotype correlation in APECED patients from Campa- nia and in their relatives. J Endocrinol Invest 2012, 35: 169-73.

21. De Luca F, Valenzise M, Alaggio R, et al. Sicilian family with au- toimmune polyendocrinopathycandidiasis-ectodermal dystrophy (APECED) and lethal lung disease in one of the affected brothers. Eur J Pediatr 2008, 167: 1283-8.

22. Tanaka H, Perez MS, Powell M, et al. Steroid 21-hydroxylase au- toantibodies: measurements with a new immunoprecipations as- say. J Clin Endocrinol Metab 1997, 82: 1440-6.

23. Chen S, Sawicka J, Betterle C, et al. Autoantibodies to steroido- genic enzymes in autoimmune polyglandular syndrome, Addison's disease, and premature ovarian failure. J Clin Endocrinol Metab 1996, 83: $2977-86$.

24. Dal Pra C, Chen S, Betterle C, et al. Autoantibodies to human tryp- tophan hydroxylase and aromatic L-amino acid decarboxylase. Eur J Endocrinol 2004, 150: 313-21.

25. Cervato S, Morlin L, Albergoni MP, et al. AIRE gene mutations and autoantibodies to interferon omega in patients with chronic hy- poparathyroidism without APECED. Clin Endocrinol (Oxf) 2010, 73: 630-6.

26. Ekwall O, Hedstrand $\mathrm{H}$, Grimelius L, et al. Identification of trypto- phan hydroxylase as an intestinal autoantigen. Lancet 1998, 352: 279-83.

27. Betterle C, Volpato M, Pedini B, Chen S, Smith BR, Furmaniak J. Adrenal-cortex autoantibodies and steroid-producing cell autoan- tibodies in patients with Addison's disease: comparison of immunofluorescence and immunoprecipitation assay. J Clin Endocri- nol Metab 1999, 84: 618-22.

28. Perniola R, Falorni A, Clemente MG, Forini F, Accogli E, Lobreglio

G. Organ-specific and non-organ-specific autoantibodies in chil- dren and young adults with autoimmune polyendocrinopathy-can- didiasis-ectodermal dystrophy (APECED). Eur J Endocrinol 2000, 143: 497-503.

29. Betterle C, Greggio NA, Volpato M. Clinical review 93: autoim- mune polyglandular syndrome type 1. J Clin Endocrinol Metab 1998, 83: 1049-55.

30. Betterle C, Zanchetta R. Update on autoimmune polyendocrine syndromes (APS). Acta Biomed 2003, 74: 9-33.

31. Perniola R, Filograna O, Greco G, Pellegrino V. High prevalence of thyroid autoimmunity in Apulian patients with autoimmune polyglandular syndrome type 1. Thyroid 2008, 18: 1027-9. 
Table 1 Anthropometric, clinical and hormonal data of patients with subclinical Cushing's syndrome

\begin{tabular}{|c|c|c|c|c|c|c|c|c|c|}
\hline $\begin{array}{l}\text { Case } \\
(n)\end{array}$ & Sex & $\begin{array}{c}\text { Age } \\
\text { (years) }\end{array}$ & $\begin{array}{l}\text { Adrenal } \\
\text { imaging }\end{array}$ & $\begin{array}{l}\text { ACTH } \\
(\mathrm{pg} / \mathrm{ml})\end{array}$ & $\begin{array}{l}\text { UFC (lg/ } \\
24 \mathrm{~h})\end{array}$ & $\begin{array}{c}\text { Cortisol } \\
\text { midnight }(\mathrm{lg} / \mathrm{dl})\end{array}$ & $\begin{array}{l}\text { Cortisol LDDST } \\
(\mathrm{lg} / \mathrm{dl})\end{array}$ & $\begin{array}{l}\text { Cortisol 1-mg } \\
\text { DST (lg/dl) }\end{array}$ & $\begin{array}{l}\text { Cortisol ALP ? 1-mg } \\
\text { DST (lg/dl) }\end{array}$ \\
\hline 1 & $\mathrm{~F}$ & 63 & $\mathrm{~L}, 30 \mathrm{~mm}$ & 10 & 66 & 8.7 & 3.5 & 2.8 & 3.3 \\
\hline 2 & $\mathrm{~F}$ & 62 & $\mathrm{R}, 40 \mathrm{~mm}$ & 15 & 72 & 14.6 & 9.6 & 5.6 & 6.0 \\
\hline 3 & $\mathrm{~F}$ & 59 & $\mathrm{R}, 23 \mathrm{~mm}$ & 5 & 23 & 2.6 & 3.1 & 2.3 & 3.8 \\
\hline 4 & $\mathrm{~F}$ & 55 & $\mathrm{R}, 30 \mathrm{~mm}$ & 11 & 32 & 5.5 & 3.6 & 4.2 & 1.7 \\
\hline 5 & $\mathrm{~F}$ & 57 & $\mathrm{~L}, 30 \mathrm{~mm}$ & 18 & 136 & 6.0 & 4.8 & 2.6 & 2.7 \\
\hline 6 & $\mathrm{~F}$ & 51 & $\mathrm{R}, 28 \mathrm{~mm}$ & 5 & 57 & 8.0 & 3.1 & 3.1 & 4.2 \\
\hline 7 & $\mathrm{~F}$ & 59 & $\mathrm{R}, 12 \mathrm{~mm}$ & 19 & 33 & 6.0 & 2.6 & 4.8 & 1.5 \\
\hline 8 & $M$ & 63 & $\mathrm{R}, 25 \mathrm{~mm}$ & 7 & 63 & 4.2 & 3.3 & 4.4 & 1.7 \\
\hline 9 & $M$ & 64 & $\mathrm{R}, 30 \mathrm{~mm}$ & 9 & 34 & 5.1 & 5.4 & 3.8 & 2.3 \\
\hline 10 & $\mathrm{~F}$ & 58 & $\mathrm{~L}, 29 \mathrm{~mm}$ & 9 & 30 & 5.0 & 2.4 & 3.4 & 2.6 \\
\hline 11 & M & 59 & $\mathrm{R}, 25 \mathrm{~mm}$ & 19 & 36 & 3.3 & 6.3 & 7.0 & 3.4 \\
\hline 12 & $\mathrm{~F}$ & 61 & $\mathrm{~L}, 12 \mathrm{~mm}$ & 16 & 38 & 7.0 & 2.7 & 2.4 & 2.7 \\
\hline 13 & $M$ & 59 & $\mathrm{R}, 15 \mathrm{~mm}$ & 11 & 30 & 4.3 & 3.2 & 2.8 & 4.5 \\
\hline 14 & $M$ & 59 & $\mathrm{R}, 15 \mathrm{~mm}$ & 12 & 30 & 4.3 & 3.2 & 2.8 & 3.6 \\
\hline 15 & $F$ & 67 & $\mathrm{R}, 12 \mathrm{~mm}$ & 11 & 79 & 4.8 & 3.6 & 2.9 & 1.7 \\
\hline 16 & $\mathrm{~F}$ & 58 & $\mathrm{R}, 40 \mathrm{~mm}$ & 13 & 35 & 3.6 & 5.0 & 3.8 & 5.0 \\
\hline 17 & $M$ & 57 & $\mathrm{R}, 28 \mathrm{~mm}$ & 10 & 54 & 4.2 & 3.1 & 4.6 & 2.7 \\
\hline 18 & M & 53 & $\mathrm{~L}, 30 \mathrm{~mm}$ & 7 & 91 & 3.1 & 4.5 & 5.3 & 1.7 \\
\hline 19 & $F$ & 42 & $\mathrm{R}, 24 \mathrm{~mm}$ & 18 & 37 & 6.3 & 2.7 & 6.0 & 5.1 \\
\hline 20 & $\mathrm{~F}$ & 49 & $\mathrm{~L}, 10 \mathrm{~mm}$ & 15 & 45 & 3.7 & 3.6 & 2.5 & 2.8 \\
\hline 21 & $M$ & 67 & $\mathrm{R}, 36 \mathrm{~mm}$ & 18 & 22 & 5.7 & 4.0 & 4.4 & 4.0 \\
\hline 22 & $\mathrm{~F}$ & 56 & $\mathrm{~L}, 30 \mathrm{~mm}$ & 19 & 128 & 4.7 & 4.2 & 4.5 & 3.1 \\
\hline Mean & & 58.1 & & 14.1 & 53.3 & 5.5 & 4.0 & 3.9 & 3.0 \\
\hline SEM & & 1.2 & & 1.5 & 3.7 & 0.5 & 0.3 & 0.3 & 0.3 \\
\hline
\end{tabular}

R, right adrenal adenoma, L, left adrenal adenoma, ACTH (pg/ml; 1 pg/ml $90.22=1$ pmol/l); UFC (lg/24 h; 1 lg/24 h $92.75=1$ $\mathrm{nmol} / \mathrm{d})$; cortisol $(\mathrm{lg} / \mathrm{dl} ; 1 \mathrm{lg} / \mathrm{dl} 927.59=1 \mathrm{nmol} / \mathrm{l})$; LDDST, low dose dexamethasone suppression test; $1-\mathrm{mg}$ DST, $1 \mathrm{mg}$ dexamethasone suppression test; ALP, alprazolam 

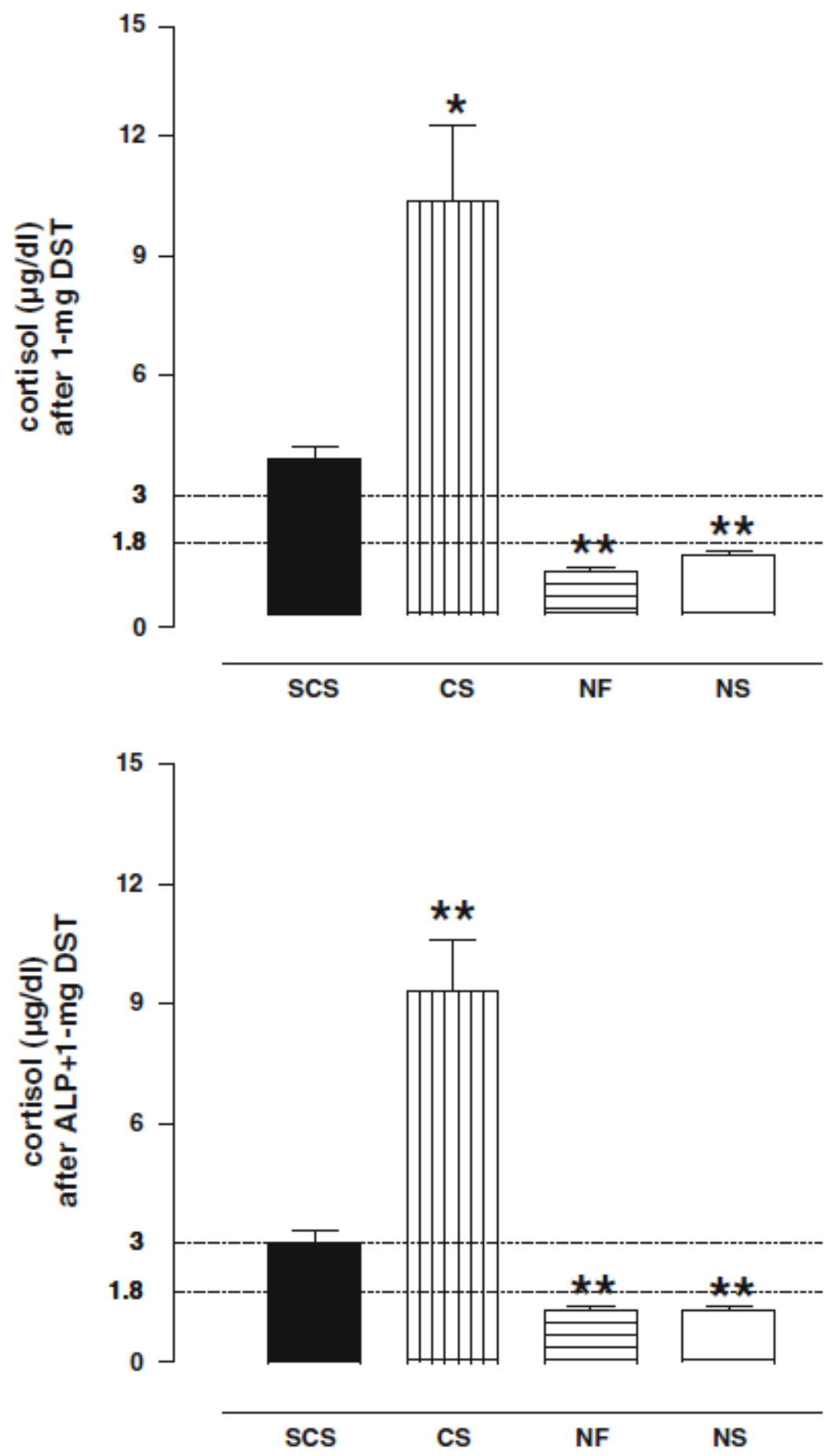

Fig. 1 Cortisol levels (mean \pm SEM, $1 \mu \mathrm{g} / \mathrm{dl} \times 27.59=1 \mathrm{nmol} / \mathrm{l})$ after $1 \mathrm{mg}$ dexamethasone suppression test (1-mg DST; upper panel) and alprazolam (ALP) + 1-mg DST (lower panel) in patients with subclinical Cushing's syndrome (SCS), overt Cushing's syndrome $(C S)$, non-functioning adrenal adenoma $(N F)$ and normal subjects (NS). $* P=0.012$ (vs. SCS); $* * P=0.0005$ (vs. SCS) 


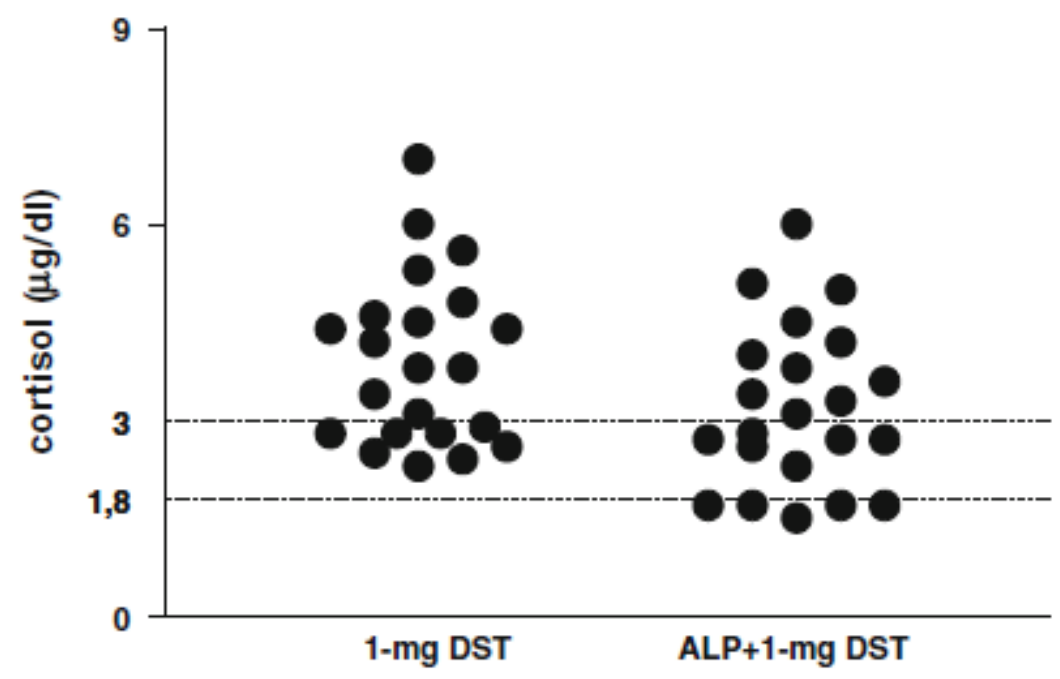

Fig. 2 Individual cortisol levels $(1 \mu \mathrm{g} / \mathrm{dl} \times 27.59=1 \mathrm{nmol} / \mathrm{l})$ after $1 \mathrm{mg}$ dexamethasone suppression test (1-mg DST) and after alprazolam (ALP) + 1-mg DST in patients with subclinical Cushing's syndrome 